\title{
Sustainability of economic growth and digital risks in regions of Russia
}

\author{
Galina P. Litvintseva*, and Ilya N. Karelin \\ Novosibirsk State Technical University
}

\begin{abstract}
Digital transformation of society which influenced all spheres of people's life can promote sustainability of economy, especially on the growth stage of its lifecycle. The research characterizes sustainability of economy as sustainability of economic growth in regions of Russia, which is estimated by variation ratio of growth rates of physical volume of gross regional product in 85 regions during 2011-2019. Positive connection between regional subindices of people's quality of life and the ESG ranking of Russian regions is revealed. It was discovered that increase of people's digital wealth positively influenced on sustainability of growth rates of gross regional product during 2015-2018. The risk of unemployment rate increase which is frequently mentioned in publications was not confirmed, namely the share of unemployed with higher education and without it as a part of relevant labor force negatively correlates with digital indices. Digitalization of social sphere and services positively influence on divorcement rate and tumor illness frequency while its decrease could result in growth of economic crimes share. However people's digital wealth could influence on decrease of share of government and municipal servicemen in regions labor force. It is advisable to count these ambiguous processes when perfecting national and regional development programs.
\end{abstract}

\section{Introduction}

Sustainability of economy is traditionally considered basing on interaction and interinfluence of economic, social and ecological spheres. Research shift to interregional and regional levels is becoming an important dimension $[1,2,3]$. Digital technologies are implemented into the mentioned spheres and new opportunities and risks of digital society appear [4, $5,6]$.

Sustainability could be evaluated with different indicators, methods and models: from elasticity functions to structural models and panel data $[7,8,9]$.

In the given research the stress on sustainability of economic growth in regions of the Russian Federation is made. Economic growth is measured with growth rates of physical volume of gross national product of the country or gross regional product (GRP) of its regions.

The degree of growth rates variability as an unsustainability characteristic is defined by us with variation ratio. Let's present statistical characteristics of growth rates variation ratio

\footnotetext{
* Corresponding author: litvintseva-g@mail.ru
} 
of physical GRP volume for 85 regions of Russia for 2011-2019 (with division by five-year periods in moving mode) Average value of variation ratios decreased from 3.417 to 2.205, the median and interval dimension declined too. Standard deviation of variation ratios is equal to 1.870 in the first of considered periods and to 1.272 in the last one (Table 1).

Table 1. Descriptive statistics for variation ratios of physical GPR volume growth rates

\begin{tabular}{|l|c|c|c|c|c|}
\hline \multirow{2}{*}{ Indicator } & \multicolumn{5}{|c|}{ Period of computation of a variation ratio } \\
\cline { 2 - 6 } & $\mathbf{2 0 1 1 - 2 0 1 5}$ & $\mathbf{2 0 1 2 - 2 0 1 6}$ & $\mathbf{2 0 1 3 - 2 0 1 7}$ & $\mathbf{2 0 1 4 - 2 0 1 8}$ & $\mathbf{2 0 1 5 - 2 0 1 9}$ \\
\hline $\bar{x}$ & 3.417 & 2.923 & 2.612 & 2.413 & 2.205 \\
\hline $\mathrm{SE}$ & 0.205 & 0.194 & 0.200 & 0.171 & 0.138 \\
\hline $\mathrm{M}$ & 3.231 & 2.625 & 2.162 & 2.083 & 1.921 \\
\hline$\sigma$ & 1.870 & 1.789 & 1.846 & 1.574 & 1.272 \\
\hline$\sigma^{2}$ & 3.496 & 3.201 & 3.407 & 2.478 & 1.618 \\
\hline $\mathrm{R}$ & 10.717 & 9.441 & 9.728 & 9.485 & 6.779 \\
\hline$x_{\min }$ & 0.601 & 0.353 & 0.276 & 0.414 & 0.379 \\
\hline$x_{\max }$ & 11.319 & 9.794 & 10.005 & 9.899 & 7.158 \\
\hline $\mathrm{N}$ & $83^{*}$ & 85 & 85 & 85 & 85 \\
\hline
\end{tabular}

* Without Crimea and the city of Sevastopol.

It is known that if variation ratio declines then economic growth and therefore economic system become more sustainable even when growth rates are quite low.

Considering specific features of the modern age the goal of the research was in defining interconnection between digital transformation of economy and its sustainability as well as in evaluation of interconnection between people's digital quality of life (PQL) and possible digital risks, which could become unwanted disturbances.

\section{Methods and database}

Digital transformation is evaluated by us with the people's digital quality of life. The evaluation of changes was done basing on computation of the integral index - the Russian regional index of digital component of people's quality of life. We used data of the Federal State Statistics Service for all 85 regions of Russia ( 8 federal districts) for the period 2015$2019[10,11]$. The results of previous series of digital index computation for the period 2015-2018 were published in $[12,13]$.

To characterize sustainability the ESG ranking of Russian regions was used, which is computed by the European rating agency RAEX-Europe (Germany). It was used as a basis for estimation of Environmental (E - Environmental) and social ( $\mathrm{S}$ - Social) risks, quality of Governance ( $\mathrm{G}$-Governance) and how effectively regions cope with these risks [14].

To make conclusions statistical and index methods were used as well as correlation analysis.

\section{Dynamics of the digital index and its interconnection with the ESG ranking of Russian regions}

In 2019 comparing to 2015 the RRIPDQL increased from 0.465 to 0.540 . The Central federal district (FD) restored its first place lost in 2018 with the index value of 0.577 . The Ural FD (digital index is 0.56), the North-Western FD (0.55), the Volga FD (0.543) are above the Russian average level, while the rest 4 districts are below it. The North Caucasus FD has the lowest value in 2019 equal to 0.415 . During 2015-2019 all FDs had positive increment of growth of the RRIPDQL. The highest index growth rates during 5 years and in the last year are in the Central FD. The Siberian FD is on the fifth place both in rank and in 
index growth rate. 5 districts were changing their ranks in growth rates in different years of the period. The Far Eastern FD turned to be on the $8^{\text {th }}$ place while its index value dropped in 2019 comparing to 2018 and its growth rate is $99.1 \%$ which is explained by joining Zabaikalsky Krai and Buryatia which are underperforming in digital development.

High positions are taken by the Yamalo-Nenets autonomous okrug (AO) (0.736), the city of Moscow (0.702), the Chukotka AO (0.615), the Belgorod and Tyumen regions (0.599), the Khanty-Mansi autonomous okrug - Yugra (0.591), the Chuvash Republic (0.589). At the end of the list are the regions of the North Caucasus FD and the Republic of Kalmykia.

It is interesting to look at the dynamics and change rates of parameters characterizing six components of people's quality of life in Russia. The information activities safety takes the first place while the quality of social sphere and services in conditions of digitalization us on the sixth one (Fig. 1).

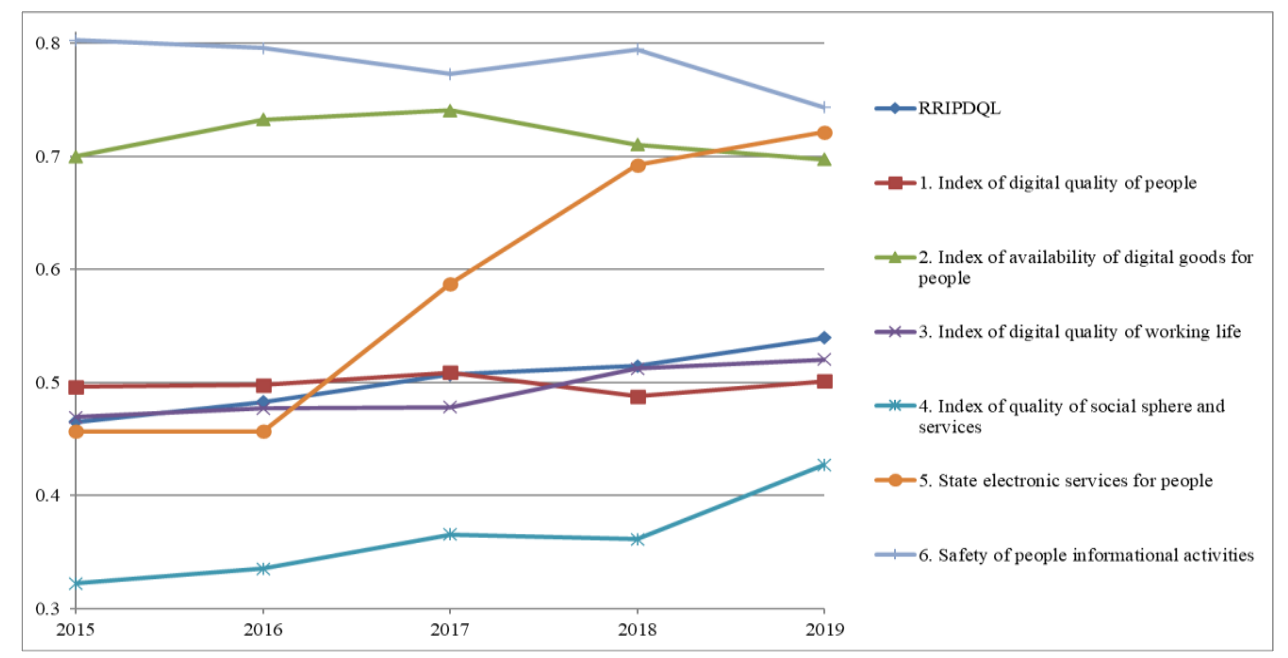

Fig. 1. The RRIPDQL and its subindices dynamics in Russia during 2015-2019

In 2019 comparing to 2015 the index of quality of state electronic services for people moved from the $5^{\text {th }}$ place to the $2^{\text {nd }}$, while the index of digital quality of people moved reversly from the $3^{\mathrm{d}}$ place to the $5^{\text {th }}$ and the index of availability of digital goods for people moved from the $2^{\text {nd }}$ to the $3^{\text {d }}$ place. Maximum growth rates during the whole period were demostrated by the index of state electronic services for people and the index of quality of social sphere and services $-158.0 \%$ and $132.6 \%$ to 2015 . Russian average growth rates are $116 \%$. The index of availability of digital goods for people $(99.6 \%)$ and the index of safety of people informational activities $(92.6 \%)$ had negative increment of growth value.

Let us briefly characterize the ESG ranking for Russian regions obtained in 2020. The Republic of Tatarstan is on the first place with high quality of governance. It is followed by the city of Moscow, the Lipetsk region (the first place of environmental risks prevention), the Khanty-Mansi autonomous okrug, the Kurgan region and the Tyumen region. The Novosibirsk region is on the $30^{\text {th }}$ place. The Nenets autonomous okrug has the best rank in social risks prevention, but the 81 th place in environmental risks. At the end of the list are the Kabardino-Balkarian Republic, the Republic of Tyva, the Republic of Kalmykia [14].

Let's consider interconnection between the authorial digital subindices and ESG rankings of Russian regions (Table 2). 
Table 2. Spearman's rank correlation ratios between ESG rating of Russian regions and ranks of Russian digital indices in 2019

\begin{tabular}{|l|c|c|}
\hline \multicolumn{1}{|c|}{ Indicator } & $\begin{array}{c}\text { Correlation to the fourth subindex of } \\
\text { quality of social sphere and services }\end{array}$ & $\begin{array}{c}\text { Correlation to } \\
\text { RRIPDQL }\end{array}$ \\
\hline Correlation ratio (R) & $0.218^{* *}$ & $0.277^{* *}$ \\
\hline Significance (2-sided) & 0.047 & 0.011 \\
\hline Number of observations & 83 & 83 \\
\hline
\end{tabular}

** significance level is less than $5 \%$.

As the correlation ratio is positive, it means that worsening region's place in digital indices ranking is connected to decrease of the region's place in the ESG ranking of regions sustainability. In other words, digital transformations in economy and especially in social sphere positively influence on decreasing risks and/or their prevention in regions.

\section{Sustainability of economic growth and risks connected to digi- talization of economy}

The question arises of whether there is a connection between the RRIPDQL subindices, general digital index and variation ratios of GRP growth as indicators of unsustainability of economy (Table 3).

Table 3. Correlation ratios of digital indices and variation ratios of GRP physical volume growth***

\begin{tabular}{|l|c|c|c|c|c|}
\hline \multirow{2}{*}{ Index } & \multicolumn{5}{|c|}{ Year } \\
\cline { 2 - 6 } & $\mathbf{2 0 1 5}$ & $\mathbf{2 0 1 6}$ & $\mathbf{2 0 1 7}$ & $\mathbf{2 0 1 8}$ & $\mathbf{2 0 1 9}$ \\
\hline Index of people's digital wealth & $-0.189^{*}$ & $-0.271^{* *}$ & -0.156 & $-0.179^{*}$ & 0.025 \\
\hline
\end{tabular}

* significance level is less than $10 \%$; ** significance level is less than $5 \%$; ** variation ratio was computed for five year period preceding a respective year in the table.

From 2015 to 2018 correlation ratios between variation ratios of GRP physical volume growth according to data for respective five years period and indices if digital wealth are negative and significant (except that for 2019). In 2019 the ratio is positive and insignificant. No significant correlation was found for other subindices. So far digital wealth is negatively connected to variation ratio of GRP physical volume growth rates, i.e. increasing of people's digital wealth positively influences on sustainability of GRP growth rates. People redistribute incomes to purchasing digital goods, improving stability indicators till 2019 in the whole.

Let's check if there is any connection between digital subindices and some economic indicators reflecting negative or unwelcome processes in the economy of Russia (Table 4).

The strongest and negative connection of share of unemployed with higher education within the labor force with higher education is observed for the index of quality of social sphere and services as well as with the RRIPDQL. Their growth stipulates declining unemployment level for this group of population. Connection of digitalization with share of unemployed with higher education within the labor force with higher education is stronger than that with share of unemployed without higher education within the labor force without higher education. The risk is that unemployment for people without higher education decreases slower than for people with higher education, therefore it is higher for the second group. 
Table 4. Interconnection of people's digital quality of life subindices and possible risks in regions of Russia in 2015-2019

\begin{tabular}{|c|c|c|c|c|c|c|c|c|}
\hline Indicator & $\begin{array}{c}\text { Determi- } \\
\text { nation } \\
\text { ratio }\end{array}$ & \begin{tabular}{|c|} 
Share of \\
unem- \\
ployed \\
with \\
higher \\
education \\
within the \\
labor \\
force with \\
higher \\
education \\
$(\%)$ \\
\end{tabular} & 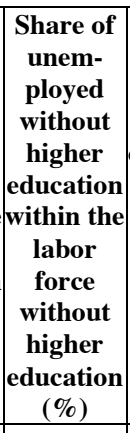 & \begin{tabular}{|c|} 
People's \\
average \\
real mon- \\
ey in- \\
comes per \\
capita \\
(rub. per \\
year per \\
capita) \\
\\
\\
\end{tabular} & \begin{tabular}{|c|} 
Total \\
divorce- \\
ment \\
ration \\
(number \\
of di- \\
vorce- \\
ments per \\
1000 \\
people) \\
\end{tabular} & $\begin{array}{c}\text { Tumor } \\
\text { illness, } \\
\text { cases per } \\
1000 \text { people }\end{array}$ & $\begin{array}{c}\text { Share of gov- } \\
\text { ernment and } \\
\text { municipal } \\
\text { servicemen in } \\
\text { state and } \\
\text { municipal } \\
\text { bodies in } \\
\text { labor force } \\
(\%)\end{array}$ & $\begin{array}{c}\text { Share of eco- } \\
\text { nomic crimes } \\
\text { in total } \\
\text { amount of } \\
\text { crimes }(\%)\end{array}$ \\
\hline \multirow[t]{2}{*}{ Subindex 1} & $\mathrm{R}$ & $-0.363^{* *}$ & $-0.250^{* *}$ & $0.429^{* *}$ & $0.288^{* *}$ & $0.254^{* *}$ & 0.012 & $-0.144^{* *}$ \\
\hline & $\mathrm{R}^{2}$ & 0.132 & 0.063 & 0.184 & 0.083 & 0.065 & 0.000 & 0.021 \\
\hline \multirow[t]{2}{*}{ Subindex 2} & $\mathrm{R}$ & $-0.227^{* *}$ & $-0.317^{* *}$ & $0.219^{* *}$ & $0.225^{* *}$ & $0.237^{* *}$ & $-0.345^{* *}$ & $0.100^{*}$ \\
\hline & $\mathrm{R}^{2}$ & 0.052 & 0.100 & 0.048 & 0.051 & 0.056 & 0.119 & 0.010 \\
\hline \multirow[t]{2}{*}{ Subindex 3} & $\mathrm{R}$ & $-0.361^{* *}$ & $-0.326^{* *}$ & $0.380^{* * *}$ & $0.379^{* *}$ & $0.252^{* *}$ & 0.021 & $-0.130^{* *}$ \\
\hline & $\mathrm{R}^{2}$ & 0.130 & 0.106 & 0.144 & 0.144 & 0.064 & 0.000 & 0.017 \\
\hline \multirow[t]{2}{*}{ Subindex 4} & $\mathrm{R}$ & $-0.440^{* *}$ & $-0.374^{* *}$ & $0.463^{* *}$ & $0.427^{* *}$ & $0.378^{* *}$ & -0.005 & $-0.232^{* *}$ \\
\hline & $\mathrm{R}^{2}$ & 0.194 & 0.140 & 0.214 & 0.182 & 0.143 & 0.000 & 0.054 \\
\hline \multirow[t]{2}{*}{ Subindex 5} & $\mathrm{R}$ & $-0.150^{* *}$ & $-0.186^{* *}$ & -0.002 & -0.064 & -0.019 & $-0.206^{* *}$ & -0.001 \\
\hline & $\mathrm{R}^{2}$ & 0.023 & 0.035 & 0.000 & 0.004 & 0.000 & 0.042 & 0.000 \\
\hline \multirow[t]{2}{*}{ Subindex 6} & $\mathrm{R}$ & $-0.128^{* *}$ & $-0.129^{* *}$ & $-0.147^{* *}$ & $0.195^{* *}$ & $0.141^{* *}$ & -0.081 & -0.05 \\
\hline & $\mathrm{R}^{2}$ & 0.016 & 0.017 & 0.022 & 0.038 & 0.020 & 0.007 & 0.003 \\
\hline \multirow[t]{2}{*}{ RRIPDQL } & $\mathrm{R}$ & $-0.483^{* *}$ & $-0.444^{* *}$ & $0.438^{* *}$ & $0.412^{* *}$ & $0.359^{* *}$ & $-0.127^{* *}$ & $-0.167^{* *}$ \\
\hline & $\mathrm{R}^{2}$ & 0.233 & 0.197 & 0.192 & 0.170 & 0.129 & 0.016 & 0.028 \\
\hline
\end{tabular}

* significance level is less than $10 \% ; * *$ significance level is less than $5 \%$; *** significance level is less than $1 \%$; *** number of observation is 425 (data for 85 regions during 5 years).

The growth of average real money income per capita is positive and is connected to the utmost to growth of the index of digital quality of people, the index of quality of social sphere and services, the RRIPDQL. In other words, declining of digitalization level in these spheres is connected to declining of real incomes.

The index of digital quality of social sphere and services as well as the RRIPDQL are positively connected to the most extent to the divorcement ratio. Higher index value suggests higher level of independence which results in unnecessity of marriage keeping when one of partners does not will to do so. This index is also positively connected to people's tumor illness. Perhaps the reason is that in regions with higher index value more high technology equipment is used which positively influences on revealing such kind of illness. Index of quality of social sphere and services has notable connection to decrease of economic crimes share. More developed social sphere promotes meeting of people's social needs in lawful manner and there is no necessity to look for illegal ways of getting services.

Index of digital wealth is connected to the most extent to decrease of share of government and municipal servicemen in state and municipal bodies in regional labor force. Implementation of projects within the "Digital economy" programs, on one hand, positively influences on sparing of working time of governmental bodies workers resulting in their 
firing and, on another hand, citizens are able to make ever growing part of operations through the portal of government services of Russia.

\section{Conclusions}

Digital transformation of economy is on the growing stage of its lifecycle and its scale effect is negligible for now. We could assume that before getting the maturity stage digital potential can promote sustainability of economy, while emerging digital risks are present but have variable and unstable nature.

In 2019 the digital index RRIPDQL grew by 0.026 comparing to its value in 2018 and by 0.075 comparing to 2015 . The leaders are the Central, Ural and North-Western FDs, while the Southern, Far Eastern and North Caucasian FDs lag significantly behind. The integral values of the Volga and Siberian FDs are closer to the average Russian level. The value of the index of safety of people informational activities decreased by 0.06 . The index of availability of digital goods for people decreased in 2019 and its value became lower than that for 2015. The index of digital quality of people got lower in its absolute values in 2019 comparing to 2017, but surpasses values of 2015 and 2016.

Interconnection was revealed between the authorial digital subindices of people's quality of life and the ESG ranking of Russian regions, which is computed by the European rating agency RAEX-Europe. Digital transformation of social sphere and services positively influence on decrease and/or prevention risks in regions.

It was found that increasing of people's digital wealth positively influences on sustainability of GRP growth rates. On the current stage of digital transformation of economy no threat of unemployment growth both for people with higher education and for those without it was revealed. However some other risks showed them up. Decrease of digitalization level in the area of people's digital quality, quality of social sphere and services in the whole economy is connected to declining of real incomes. The index of digital quality of social sphere and services is positively connected to divorcement ratio and to tumor illness of people. Its decrease could result in growing of economic crimes share in the total amount of crimes. Digital wealth of people influences on decrease of share of government and municipal servicemen in state and municipal bodies in labor force of a region.

These conclusions could be used for formation of digital economy theory and for perfecting of regional development programs.

\section{Acknowledgements}

The reported study was funded by the Russian Foundation for Basic Research (RFBR) according to the research project № 19-010-00195\21.

\section{References}

1. A. Fomin, P. Lepekhin, V. Gorbunov, International Agricultural Journal 1, 139 (2021)

2. N.Yu. Nesterenko, N.V. Pakhomova, K.K. Richter, St Petersburg University Journal of Economic Studies, 2, 217 (2020)

3. T.S. Hdeib, Journal of Economy and Entrepreneurship, 6, 1106 (2020)

4. G. Litvintseva, I. Karelin, The proceedings of the 20th International Scientific Conference "Globalization and Its Socio-Economic Consequences", SHS Web of Conferences, 92 (2021)

5. M.Yu. Arkhipova, V.P. Sirotin, Economy of region, 3, 670 (2019) 
6. M.A. Eskindarov, V.V. Maslennikov, O.V. Maslennikov, Finance: theory and practice, 5, 6 (2019)

7. G.P. Litvintseva, A.I. Karpovich, Advances in Economics, Business and Management Research, 131, 707 (2020)

8. A. Behl, A. Pal, International Journal Innovation and Sustainable Development, 1, 1 (2019)

9. M. Kaneva, G. Untura, Growth and Change, 1, 301 (2019)

10. Regions of Russia. Social and economic indicators (2020) https://rosstat.gov.ru/

11. Information society in the Russian Federation (2020) https://rosstat.gov.ru/

12. S. Petrov, M. Maslov, I. Karelin, Studies in Business and Economics, 2, 115 (2019)

13. G.P. Litvintseva, I.N. Karelin, Terra Economicus, 3, 53 (2020)

14. ESG Rating of Russian regions (2020) https://sdpl.ru/ 